UDK 351.78

https://doi.org/10.18485/fb_ic4hs.2018.29

\title{
HUMAN SECURITY - DEFINING AND APPLYING THE CONCEPT
}

\section{Emil Sloth PEDERSEN*}

\begin{abstract}
Since the conception of the concept of human security it has been the center of great debate. A part of this debate concerns what the human security concept points to in the world. I outline three positions on the ontology of human security. Human security as (1) a subject matter than can be universally defined, (2) as defined by headlines of political programs (3) as a discipline with norms, standards and methods. I analyze how these definitions of human security make for quite diverse interpretations of the role of human security in the world. This is part of an important assessment of the role of human security in dealing with a long list of challenges to the wellbeing of people all over the globe. I contribute to this assessment by discussing the role of human security in tackling challenges related to the environment and natural resources. These challenges are numerous and include global climate change in its totality, which pose a threat to the human lifeform, but also a variety of smaller and larger challenges some of which are related to climate change, some of which are not. I argue that the position from which human security best guide academic study and policy-making is as a discipline. I show the relevance of this argument in a case of natural resource management in Ghana. Analyzing this case, I show how the methodologies of the discipline contribute to a socially and environmentally sustainable management of natural resources. I discuss whether the experiences from the case-work can be extrapolated to other work dealing with sub-global challenges to human well-being and dignity. Finally, I discuss the transformative potential of the human security discipline in mitigating global climate change specifically and global challenges to human well-being more generally.
\end{abstract}

Kewords: human security, environment, climate change

\section{INTRODUCTION}

Human security - it sounds like something everyone would agree upon but this is not so. Since the conception of the concept it has been the center of great debate. A part of this debate is ontological, concerning what the human security concept points to in the world. In this paper, I outline three positions on the ontology of human security. That of human

* MA Student, Aarhus University, Denmark, emil497@hotmail.com 
security as (1) a subject matter than can be universally defined, as (2) defined by headlines of political programs; or as (3) a discipline with norms, standards and methods. These three definitions of human security, make for three quite diverse interpretations of the role of human security in the world, which I will delve into in the first part of this paper.

This discussion is not merely a theoretical exercise. It is part of an important assessment of the role of human security in dealing with a long list of challenges to the wellbeing of people all over the globe. I contribute to this more general assessment by discussing the role of human security in tackling challenges related to the environment and natural resources. These challenges are numerous and include global climate change in its totality, which pose a threat to the human lifeform, but also a variety of smaller and larger challenges some of which are related to climate change, some of which are not. Against the backdrop of this discussion, I present insights into the potential of human security in tackling challenges to human rights, human well-being and human dignity at the global level as well as at the sub-global levels.

I begin by analyzing the three positions and argue that the position from which human security best guide academic study and policy-making is by thinking of human security as a discipline. I then show the relevance of these arguments in a case on challenges related to natural resource management in Ghana. Analzying this case of foreign-company encroachment on the land on which indigenous community depends, I show how the methodologies of the discipline contribute to a socially and environmentally sustainable management of natural resources. Subsequently I discuss whether the experiences from the case-work can be extrapolated to other work dealing with challenges related to the environment and natural resources specifically and other non-global challenges to human well-being in general. Finally, I will discuss the transformative potential of the human security discipline in mitigating global climate change, the elephant in the room when assessing any environmental and natural resource related challenge. This will offer insights into general challenges for the success of the human security endeavors at the global level.

\section{HUMAN SECURITY AS (1) SUBJECT MATTER, (2) POLITICAL USE OR (3) DISCIPLINE}

\subsection{HUMAN SECURITY AS A SUBJECT MATTER}

"Existing definitions of human security tend to be extraordinarily expansive and vague, encompassing everything from physical security to psychological well-being, which provides policymakers with little guidance in the prioritization of competing policy goals and academics little sense of what, exactly, is to be studied" (Paris, 2001, p. 88).

This quote by Roland Paris exemplifies the first position that I want to draw forth; human security as a subject matter. Paris does not believe human security is defined by what policy-makers do under the heading of human security. Rather, human security are phenomena that academics could study and that policy-makers could then seek to reach e.g. like economic growth. This idea was first propelled, at the end of the Cold War, by 
scholars who wanted to break with the narrow focus on the political and military sector as the 'referent object' of study within classical security complex theory of International Relations (Buzan, Wæver \& de Wilde, 1998, p. 15). The focus was sought widened to draw attention to the urgency of non-military threats (Buzan, Wæver \& de Wilde, 1998, p. 2). Although the positions were many, one trend that emerged was that under the heading 'human security' the scope of threats to be regarded were the negative counterparts to 'the seven pillars of human security' as they were formulated by the UNDP in the 1994 Human Development Report. Namely threats to personal-, political-, economic-, health-, environmental-, community- and food-security.

For Paris, this list is so broad as to mean everything and thus nothing: "if human security is all these things, what is it not?" (Paris, 2001, p. 92). If we assume Paris' premise, that human security refers to a subject matter, then I agree that it is very hard to discern the boundaries of this subject matter in the debates on human security. This is not to say that the concept could not be narrowed down in specific application. Certainly, we could say that in a concrete case of water-shortage, striving towards human security would first and foremost be about securing a water-supply. But as Paris points out, it will be hard to reach any consensus on what the concept should be narrowed down to. As a subject matter, human security cannot in any coherent way guide academic study and policy-making. This is suboptimal, and looking at the third position, I will show that not accepting Paris' premise holds a greater promise for guiding academics, development practitioners, businesses and policy-makers alike in a coherent fashion. Before doing so, I will turn to the position that human security is defined by its political use.

\subsection{HUMAN SECURITY AS POLITICAL USE}

"14 years after human security was first taken up by the United Nations, its integration into the policymaking and policy practices of leading Western states and international institutions has revealed that talk of two different 'paradigms' - the radical counterposition of 'individual' and 'state-based' approaches, or between 'critical theory' and 'problem-solving' frameworks - has been much exaggerated" (Chandler, 2008, p. 427f)

This statement made by David Chandler exemplifies the second position that I want to draw forth from the debate on human security: that the meaning of the concept of human security is derived from its use in policy-making of leading Western states and international institutions. From this position, the evaluation of the novelty and accomplishments of human security is based on these policy practices. For Chandler, unlike proponents of other positions, human security is not defined by the framework of human security from the 1994 UNDP publication. This is also the premise of his critique; that human security is not the transformative concept that others claim it to be: "Human security is 'the dog that didn't bark', in that its integration into the mainstream of policymaking has reinforced, rather than challenged, existing policy frameworks" (Chandler, 2008, p. 428).

This criticism needs nuance as the state and international organizations policies under the heading of human security are diverse. In some cases, the language of human security has been transformative like UN operations on police-reform, disarmament, peace in relation 
to vulnerable groups, and women and peacebuilding (Krause, 2014, p. 83). Despite this, Chandler is right that most of the policies undertaken in the name of human security have centered on securing individuals from threats of violence. These policies then resemble a security focus somewhere in between the narrow focus of traditional security policies and the much wider focus of the 'seven pillars' promoted in the 1994 UNDP Human Development Report (Krause, 2014, p. 84). Although Chandler might be right in his critique of the policies under the banner of human security, I do not accept his premise that human security is defined solely by its use in these policies. If we accept other definitions of human security, like for example the definition in the 1994 UNDP report, we may instead claim that there is a great gap between the human security concept, and the practices of many states and international organizations in the name of human security (Krause, 2014, p. 76).

\subsection{HUMAN SECURITY AS A DISCIPLINE}

The third position that I want to draw forth is the position that human security refers more to a way of working, than to a subject matter to be worked with or to the policy-practice under the human security heading. We find this position expressed by scholars like Des Gasper who argue that human security is a 'language' or a way of 'thinking' that is defined less by what it thinks about and much more by how it does so and how these thoughts are expressed in stories (Gasper, 2013, p. 69). We also find the position expressed in the United Nations Trust Fund for Human Security (UNTFHS) publication 'Human Security in Theory and Practice' (2009). Although this publication also cites the seven pillars of human security as avenues of study the recurrent theme of the publication is the 'operationalization' of human security, and the focus on human security as an 'approach' rather than the demarcation of subject matter onto which this approach should be applied.

This proposition is not merely an afterthought to gloss over the failures of human security as subject matter or policy-practice. Already when the concept was first promoted by the UNDP in 1994 it was expressed as an attempt to "redefine humanity's development agenda" (UNDP, 1994) this meant changing the way development was practiced. This must be seen in light of the post-Cold War context where the UN sought to reconcile the two generations of human rights, namely, the first generation of civil and political rights and the second generation of economic and social rights. The two had previously been separated along the Cold War divides. In line with reconciliation the UNDP effort presented a conceptual triangle in which the rethinking of development through the concept of human security was seen as the "condition for human rights [of all generations] to be fulfilled" (Tadjbakhsh, 2014).

I want to make the case that this position of human security is that the concept of human security refers to a discipline. I define discipline as a practice about instruction on-, the shaping of-, and communication of- a field of knowledge, with certain norms and standards but with a, possibly, wide variety of approaches (Schanz, 2012). Thus, a discipline is not as much characterized by what is studied, as by how it is studied.

In the 1994 UNDP report and in the 2009 UN Trust Fund for Human Security publication 'Human Security in Theory and Practice' we find a range of norms that shape the 
discipline of human security. First and foremost, there is the norm of protecting human rights and ascribing equal value to the economic, social, cultural, civil and political rights including the right to food. Further, it is non-discriminatory when it comes to gender, religion, race or ethnicity. It is 'multi-sectoral' in the challenge-analysis and the planning, coordination, and evaluation of solutions with regards to what challenges and solutions are considered, moving beyond a mere concern with military or other violent threats; with regards to where challenges and solutions are considered, moving across and beyond institutional divides like state boundaries; and with regards to how challenges and solutions are considered, moving across academic boundaries. It is 'prevention-oriented'; challenges are to be tackled at their root causes, in their earliest stages and be long term sustainable both socially and environmentally._Within human security there is a norm of working towards the two mutually reinforcing goals of protection and empowerment. Protection is a top-down perspective recognizing that threats are at times beyond the control of people and that national and international institutions and organizations then have a responsibility to protect these people, rather than focusing on e.g. protecting economic assets. Empowerment is a bottom-up focus on enabling people to develop resilience to difficult situations including preventive local-capacity building (UNDP, 1994 \& UNTFHS, 2009). As a discipline, human security is also characteristic because of its normative nature. With an explicit norm of being transformative in improving the livelihood of others, human security resembles newer disciplines like development studies. I contend that another aspect worth noting about human security as a discipline, is its methodological characteristics. These are different from traditional security studies in combining the quantitative, distanced methodology of this older field with a more integrative, consultative, qualitative methodology (Martin \& Kostovicova, p. 298) usually found within the humanities in e.g. sociology and anthropology. The UNTFHS publication calls this context-specific, and people-centered (2009), emphasizing that the analyst must acknowledge differences across different settings, seek contextualized inclusive analyses and solutions that are based on local assets for coping. Further, she must be complimenting this with quantitative indicators. Thus, human security is at its methodological core interdisciplinary.

We find these norms and methodologies institutionalized since 1994 under the heading of human security in university courses and research projects at prestigious universities (Paris, 2001, p. 87; Krause, 2014, p. 81), in handbooks (UNTFHS, 2009), and in publications like the Human Security Report (Krause, 2014, p. 81). Despite this, I have not been able to find any use of the term "discipline" about human security. Thus, in a reversal of the old fairy-tale (Andersen, 1991) it seems that a lot of people are aware of the 'clothes' - the norms, methodologies and institutionalization - of human security but no one shouts that it is 'well-dressed' - that it is a discipline. It does however seem obvious once declared. It is worth noting that human security as a discipline is not merely an academic practice confined to universities and scientific journals. As mentioned the concept was first promoted by the UNDP in 1994 in an attempt to "redefine humanity's development agenda" (UNDP, 1994) this meant changing the way development was practiced across 'humanity' including in academia, in ministries, NGO's and in international institutions. 
The extent to which this change of practice has materialized at different levels is beyond the scope of this paper. Instead, I investigate the potential for change that this practice holds. Thus, I will turn again to Paris' critique that human security cannot guide the study of academics or the action of policy-makers, and look at how this may not be the case if we think of human security as a discipline.

\section{THE PROBLEM OF DEFINITION}

As mentioned, Paris argued that the scope of the subject matter of human security makes it impossible to prioritize goals for politicians and to discern what is to be studied by academics (Paris, 2001, p. 88). This resembles a point made by David A. Baldwin, who argues that "conceptual clarification logically precedes the search for the necessary conditions of security, because the identification of such conditions presupposes a concept of security" (Baldwin, 1997, p. 8). In other words, what constitutes security needs to be specified before we can promote security (Paris, 2001). I believe this clarification is necessary, but only problematic, when thinking about human security as a subject matter. I do not believe these problems are necessarily present if we think about human security as a discipline. With the disciplinary norm of participation in mind this conceptual clarification of security need to be done in situ, with the people affected. Inspired by Nils Bubandt we may say that the security concept of human security is vernacular, meaning site specific (Bubandt, 2005, p. 276). This is not working from a pre-established universal concept of human security as the what, the subject matter of human security, as Paris demands. Rather it is working from the notion that what constitutes security is always socially and discursively situated (Bubandt, 2005, p. 275). Thus, the analyst should allow for ideas about security that may not reflect "the dominant political agenda", which is why the approach has been called emancipatory (Tadjbakhsh, 2014, p. 46). Being attentive to this, the human security analyst investigating site-specific meanings of security can find help clarifying priorities and objects of study by asking seven questions put forth by Baldwin. (1) Security for whom (2) securing what (3) security from what (4) security to what degree (5) security at what time scale (6) security with which means (7) security at what costs (Baldwin, 1997). Answering these seven questions will bring forth a very clear concept of vernacular security, useful in the assessment of threats, and useful in guiding the action of potential policy-makers. This work is possible, despite being developed within a very broad discipline of human security.

In sum, academics, NGO's, businesses, governments and international institutions working within the discipline can work with a multitude of cases, but their work will not be random, or without useful conclusions. Instead, the work within this discipline, due to the norms and methods, will help policy-makers gain knowledge about vulnerable individuals and communities and will help them make qualified decisions to improve the vernacular human security of these individuals and communities. In the following, I present a case example to show the discipline in practice.

\section{SITUATING HUMAN SECURITY}

Before presenting the case, I want to note that the work done in the case was not done explicitly within the 'discipline' of human security. The term 'discipline' is not used for 
the human security approach although as I have argued it lives up to the criteria for a discipline. Through my analysis of the case it will be clear that the work meets the norms and methodologies of the discipline of human security especially the standards of using a participatory, prevention-oriented, and human rights centred approach.

In Ghana, as in many other countries, large-scale land acquisition detrimental to local communities is a great challenge. This challenge is in part constituted by a national legal system within which community land is in fact state owned and power asymmetries between the affected communities and the foreign-based companies trying to acquire land (Akologo \& Guri, 2016). The Centre of Indigenous Knowledge and Organizational Development (CIKOD) worked with the local community of Tanchara to deal with the challenge of large-scale land-acquisition. In 2000 the Ghanaian government granted an Australian gold mining company the right to prospect for gold within the community area without informing or involving the community in the decision (Guri Yangmaadome et al., 2012, p. 124).

The approach that CIKOD applied falls within the norms and methodologies characteristic of human security as a discipline. With regards to norms, CIKOD sought to protect the human rights of the villagers, namely the human rights of indigenous communities to free, prior, informed consent regarding changes that affect their means of subsistence, cultural practices and traditional sites (UNDRIP, 2008). It did so, in what is a good example of the norm of top-down protection based on the acknowledgement, that local people may not hold all the means to tackle threats. Protection was sought top-down as CIKOD mediated support to the community from the Ghanaian Commission on Human Rights And Administrative Justice (GCHRAJ) (Akologo \& Guri, 2016). External protection was sought in acknowledgment that the government decision also needed to be fought through legal expertise which the local community did not hold. The GCHRAJ provided the protection of legal frameworks by mapping the rights of the community according to customary, national and international laws and conventions (Guri Yangmaadome et al., 2012, p. 127).

The work of CIKOD also followed the human security disciplinary norm of empowerment working bottom up to develop resilience to difficult situations among the affected. This was done in a people-centered, context-specific manner as CIKOD sought to "understand and work within the communities' own worldview" (Guri Yangmaadome et al., 2012, p. 122). Thus, the assessment of threats to the community; the assessment of the community assets that could be used; and the planning of how to reach a more secure future; was all made by the community itself. The tools for doing so were provided by CIKOD. Made by the community itself, the assessment of threats and strategies for action was multi-sectoral including aspects from arenas, that are sometimes separated by disciplinary standards such as the threat to community coherence, the need for political attention, and the potential health and economic threat of prospected mining (Guri Yangmaadome et al., 2012). In other words, a vernacular, emancipatory concept of security and security-threats was developed.

Additionally, the work done by CIKOD was prevention-oriented. Root-causes of the challenges were taken on at the early stages before mining was underway and this gave enough 
time to start processes towards socially and environmentally sustainable long-term solutions, based on vision-statements of where the community wanted to be 10 years ahead (Akologo \& Guri, 2016). There is a clear testimony to the empowerment of the community through increased awareness of local assets, and through the awareness of being protected by national and international legal frameworks in the processes and changes adopted by the community. To name a few: since 2004 biannual meetings have been organized to review activities and present projects to external actors on how to secure the community livelihood and its rights. The community has improved environmental sustainability of the sacred groves by implementing organic, zero tillage land-use with traditional crop varieties. In turn, this has strengthened the community authorities that depend on these groves. The women of the community are now better organized and increasingly do farming as an economic activity which increases their voice in the community. This is an example that the human security approach is not merely conserving indigenous communities, but is transformative while respecting community practices (Guri Yangmaadome et al., 2012, p. 123). The perhaps greatest example of community strengthening is the fact that local workshops on the impact of gold-mining lead to regional forums in which a joint-statement of strategies were made to deal with the problems associated with goldmining. At these forums goldmining company representatives also participated and for the first time engaged with the local communities (Guri Yangmaadome et al., 2012, p. 126). At the forum, the government and the mining company was informed about how to engage with the community in order to ensure free, prior and informed consent, this included the statement that the community had the right to say no to any dispossession. In the end goldmining was postponed indefinitely in the area and the community reached its vernacular goals for security (Akologo \& Guri, 2016, p. 39).

This case shows that within the discipline of human security, it is indeed possible to narrow down, apply and prioritize ideas of human security. We see that in this concrete case, we can easily answer Baldwins seven questions (1) the Tanchara community consisting of 3800 members were the ones for whom security was at stake, what needed to be secured (2) was their land on which they heavily depended for their livelihood and which held great spiritual significance for the village as well. (3) The community access to land needed to be secured from the encroachment of mining companies that were active in the region. (4) This needed to be done to the degree that access to the land was not lost at all and natural resources were not degraded (5) in the following 10 years. $(6 \& 7)$ This was to be ensured using the resources within the community; through regional forums and via the existing community, national and international legal frameworks.

If we accept this as an example of work within human security as a discipline then this case shows that by following the norms and methodologies of the discipline, fruitful work can be done to tackle environmental and natural resource challenges. Further, nothing in the case indicates that the success of the human security practice was conditioned by the fact that this was a natural resource challenge. The case analysis also shows the clear advantages of considering human security as a discipline rather than a subject matter or defined by the use of policy-makers. As a discipline, the subject matter of human security was not predetermined in the Tanchara case, rather it was context-specific and this guaranteed the relevance of the work done. Also, the political efforts were not defined by 
an existing political human security agenda, directly opposite the political efforts were guided by the work done according to the norms and standards of case analysis within the human security discipline. The case shows that strategic priorities were made both in the analysis of the challenges, and in guiding the relevant actors in taking action. In this quite small-scale case, the actors were the affected community. But CIKOD has also used the case to provide guidance to policy-makers at the national level on how to improve the process of reaching free, prior, informed consent of local communities in cases of largescale land deals.

In the following, I discuss how the insights from this case analysis apply in general to the analysis and policy-guidance within the human security discipline, when considering the wider scope of challenges to human rights, human dignity and human well-being.

\section{HUMAN SECURITY CHALLENGES}

The variety of human security challenges is unfathomable. The amount of people affected by these challenges range from a single individual as the case of a lone person's isolated house catching fire from a lightning to potentially everybody on the planet as the case may be with global warming in its totality and the connected avalanche of negative snowballing side-effects that are still being realized. Some issues are confined within local, national or regional political boundaries, others are constituted partially by these boundaries themselves as is the case with trans-boundary crime (see e.g. Van Schendel, 2005), and yet others simply override any such boundary. Some are confined to a short span of time, others have effects that potentially outlast the next many generations to come. I will deal with this great span of challenges and the potential of the human security discipline in two sections. First by considering challenges that are less than global. Secondly, considering global climate change in its totality as a potential threat to the human life form and discussing the great methodological challenges that global issues in general present to the discipline of human security. I will argue that despite these challenges human security analysis may be an important life rope away from climate disaster and other global challenges to human well-being.

\section{HUMAN SECURITY AND LESS THAN GLOBAL CHALLENGES}

The discipline of human security can contribute to many of the challenges to human wellbeing and upholding of human rights if these challenges are narrowed down to concrete instances e.g. the problem of smog in Beijing or the dangers involved in irregular migration from Cheran in Southern Mexico. The human security analyst will be able to engage with more localized challenges of protection, adaptation, and prevention: protection from e.g. disease outbreaks or ethnic violence; adapting livelihood practices to e.g. mitigate the effects of changing weather patterns by e.g. changing the type of crop grown; preventing further contribution to the deterioration of livelihoods by altering key practices of e.g. decision-making, consumption, production or interaction. In order to meet the standard of promoting sustainable solutions, these three elements should all be included in the analysis and policy-guidance. Across the spectrum challenges, the case analysed earlier is instructive, in deciding the subject matter on which the discipline holds 
the greatest potential. The participatory approach demands an inclusion of the affected parties in the assessment of what constitutes a threat, and what constitutes security. If this is possible, then human security as a discipline will benefit from not being constrained to look only within certain sectors like the political or the military. Rather the human security analysts can follow linkages seamlessly across sectors as they are developed by study subjects. This context-specific, people-centred, multi-sector perspective aimed at empowerment avoids proposing policies merely because they fit institutional frameworks but insists on a bottom-up approach, rather than one-size-fits-all solutions. Human security with its emphasis on both empowerment and protection is theoretically useful in tackling any challenge to the upholding of human rights, well-being and dignity. But it is worth noting, that as protection relies on the 'goodwill' of the relevant external protectors, this may be hard to attain, and poses a difficulty within the discipline. An example of this is the prospecting of new coal plants in China by the Chinese government, despite people protesting the lethal smog of Northern China that annually leads to one million premature deaths (Carney, 2017). In this case the protector is clearly not taking the needed responsibility. Despite this difficulty, even in cases where the immediately relevant institutions do not adhere to their responsibility to protect vulnerable people threatened by things outside their control, the work within human security as a discipline increase the chance that protection will manifest. It does so because it empowers the people affected and gives these people a voice via the human security analysis. The policy-guideline that arise from this analysis makes it clearer what protective action is needed and thus makes it easier for the relevant external actors to engage in. This lesson can also be drawn from the case example from Ghana. Here the government initially failed to meet its responsibility to protect the local community rights, as prospection rights were given to the foreign company. Only later, after the empowerment of the local community, is the government starting to take responsibility to protect. The government has also praised the involved organizations for emphasising the government responsibility and drawing up the needed action (Danso \& Donkor, 2017). Further, the mining company after the empowerment has delayed action in what can be interpreted as an acknowledgement of community rights and of the company's role as the principal agent of threat.

\section{HUMAN SECURITY AND GLOBAL CHALLENGES}

A range of threats to humans are of a nature that cannot meaningfully be called merely transnational or regional but are rather international or global. Among them are the proliferation of nuclear technology, the development of multiresistant diseases, global financial downturns and global climate change. Other threats in this category do not necessarily affect people worldwide, but need strong global decision-making organs to protect the rights, well-being and dignity of specific populations. These threats include the conflict in Syria and dangers involved in international irregular migration. To analyse the potential of human security in dealing with these global challenges I focus on global climate change, and draw wider lessons from this.

The threat of global climate change is imminent. By the most negative estimates, global carbon emissions have already exceeded the level below which we could expect that the 
environment would not be so significantly altered as to render our societies unsafe (Gasper, 2013, p. 63f). The level of disruption is however relative to the continued emissions, and so preventive action is still meaningful.

Taking on global challenges, human security as a discipline faces two perhaps insurmountable methodological challenges. The first challenge is that at a global level the analyst cannot realistically hope to work in a 'people-centered' fashion. Establishing a vernacular concept of security is close to meaningless when considering the enormous differences in the assessment of what constitutes threats and what constitutes security, when discussing global challenges in each their, often interrelated, totality. As Naomi Klein has described in the article "Disaster Capitalism", some people are making a living selling security products in high-threat situations (Klein, 2007). These people, along with all the people and states whose immediate prosperity depends on disaster propelling businesses like fossil fuels, offensive weaponry, human trafficking or high-risk financial transactions are not likely to express threat assessments that can be easily conflated with those who are the most at risk from global challenges, those who depend the most on disaster preventive efforts, or those who know the most about implications of these global challenges. In that case, asking Baldwins seven questions will only provide answers that serve particular interests, and not the interest of the whole affected populace. In other words, within human security there is no meaningful analytical scale at which the totality of issues like global climate change can be gauged, no scale at which the 'world society' can be gauged as a coherent whole. Thus, as a proxy, the human security analyst would have to make do with an institution that could speak on behalf of the world community on these issues. But as Ulrich Beck has pointed out in his 2009 book 'World at Risk', international climate politics are still the politics of nation-states, although perhaps nationstates with a cosmopolitan outlook influenced by a range of international organizations (Beck, 2009, p. 103f). This is so despite a myriad of actors coming together in collaboration to counter global warming. I would argue that Beck's analysis is also valid for the other global threats, although in some instances with an even smaller degree of a cosmopolitanism because the negative consequences of other global issues, like the conflict in Syria are more unevenly distributed than the case is for climate change. In any case supranational institutions of cooperation and consensus building that effectively can deal with global threats to human rights, well-being and dignity are yet to emerge (Beck, 2009, p. 92). This makes the people-centred and vernacular approach within human security impossible to follow even when 'the people' are substituted by a proxy institution.

If Ulrich Beck is right in his analysis, there is also a second methodological challenge for human security that applies to all the global scale issues: Without the supranational institutions that Beck talk of, there is no proper organ that holds the responsibility to protect the global population, and no single nation can lift such challenges on their own. Thus, human security can only hope to empower since there is no one to call forth to protect. This becomes especially problematic regarding the specific threat of global climate change with due to its inbuilt mechanism of negative feedback loops and its spill over consequences into other challenges like poverty, irregular migration, and widespread conflicts like the one in Syria. As the forecasts for climate change steadily grow darker, 
with the 2-degrees goal from the Paris climate accords still more unlikely to be met (Wallace-Wells, 2017), the people of the planet can increasingly be said to be at a threat beyond their control. As stated, in these contexts human security cannot call upon a global guarantor of democratic oversight, but can only seek to empower at non-global levels

Empowerment in itself is not insignificant. Des Gasper, has argued that human security holds a transformative potential for the needed global climate action. According to Gasper such action is premised on three 'value transitions':

"from a preoccupation with the acquisition and consumption of commodities towards a broader and deeper picture of what gives quality of life; from an overwhelming individualism towards human solidarity, based on respect for all individuals; and from an attitude of mastery and domination of nature towards an attitude of stewardship for 'Mother Earth'" (Gasper, 2013, p. 71)

Gasper believes that such transitions, although far from being realized, are possible because the 'language' of human security connects to 'human subjectivity' and the 'texture of everyday life' and thus holds an 'explanatory force and motivational power' that is not present in other 'languages' like economic development or human rights (Gasper, 2013, p. 68f). Gaspers claim is that the empowerment of the human security method, giving a voice to those who are the most affected by global $\mathrm{CO} 2$ emissions, can create the needed subjective connectivity to the greatest emitters that trigger the needed value transition among these emitters. This may lead to protective action, although one that is uncoordinated from above. Combined with the small-scale contributions to protection, adaptation and prevention made by the individual human security projects, this contribution through storytelling may be an important life rope out of climate disaster.

Gaspers point about the power of the human security language is not only relevant regarding climate change. It resonates Johan Galtung's points about international efforts towards a more peaceful society. He argues that the lack of a democratic global guarantor of peace can only be compensated for by working at all levels to increase democratic governance, human rights and fairer trade deals:

"The hypothesis would be that once the system has attained a certain level of diversity, then diversity will, through symbiosis, generate more diversity. Diversity will feed on itself, so to speak. The result will be an increasingly resilient system, able to withstand injury from within and without" (Galtung, 1996)

Thus, a circular logic is at play in which the only way to move forward is to move forward, the increasing benefits of the small steps at local promotion of human rights and democratic governance will increase the ability to take further steps toward peaceful global governance (Galtung 1996). Based on my presentation of the human security as a discipline and my case-analysis of its merits I argue that human security is a practice that holds the potential to increase the length and stability of these steps both small and large. 


\section{CONCLUSION}

I've made the case that a lot of the criticisms that are raised against human security, do not apply if we think of human security as a discipline institutionalized in university courses, research projects and handbooks, and having certain norms and standards useful in the work of NGO's, businesses, governments and international institutions. Instead of working from a pre-established concept of security, the disciplinary approach is about defining threats and what constitutes security in participation with the people studied.

As a discipline, human security seeks to empower the people at threat. Based on a case analysis I showed an example of how this has been done. A vernacular definition of threats and what constituted security was established by the affected community. By letting these people identify their own assets and how they could be used, these people were given a voice and were enabled to better use their own assets. The case analysis also showed how the human security discipline can contribute to guiding the action of those who have a responsibility to protect vulnerable people. This protective aspect is enhanced by giving a voice to those who need protection, and by drawing up a clear path of action that the protectors can follow to meet their responsibility.

The lessons drawn from the case, can be used in analysis and policy guidance for a broad spectrum of challenges related to all the pillars of human security. The criteria for this is that the concrete cases have identifiable people at threat who can voice their vernacular ideas of security and its threats. This is the primary measure for the applicability of the human security methodology. I have argued that in these cases the methodology would contribute to solutions to all challenges to security.

Finally, I pointed out that global threats to human rights, human well-being and human dignity, poses methodological challenges to human security as a discipline as no vernacular concept of security or of the threats can be established neither directly nor through proxy representative organs. Despite this, the smaller scale case-work within the discipline contributes to the mitigation of such global challenges in two ways. By facilitating protection, adaptation, and prevention in local settings, meaning that this setting becomes more resilient and contribute less to threatening practices such as carbon emissions, poor governance, economic exploitation and offensive arms trade. And secondly, by mediating stories of threat and insecurity that facilitate a subjective connectivity between the most affected and the most contributing. Inspired by Gasper and Galtung, I argued that this could provoke the needed value change among the greatest instigators of global issues. Complimenting Galtung I further argued that the discipline of human security can facilitate the small and diverse steps towards a more democratic global order that promotes human rights, human dignity and human well-being.

\section{BIBLIOGRAPHY}

Akologo, S. Z. \& Guri, B. Y. (2016). Unmasking Land Grabbing in Ghana. Accra: Caritas-Ghana. Pp. 32-43

Andersen, H.C. (1991). 'Keiserens nye Klæder' in Andersen, H.C. Samlede Eventyr og Historier, 7th edt., pp. 74-76, Odense: Hans Reitzels Forlag 
Baldwin, D. A. (1997). The Concept of Security. Review of International Studies, 23(1), 226

Beck, U. (2009). World at Risk. Cambridge: Polity Press

Bubandt, N. (2005). Vernacular Security: The Politics of Feeling Safe in Global, National and Local Worlds. Security Dialogue, 36(3), 275-296

Buzan, B., Wæver, O. \& de Wilde, J. (1998) Security: A New Framework for Analysis. Boulder: Lynne Rienner Publishers

Carney, M. (2017). China's air pollution crisis shows no sign of ending as nation fails to lower coal use. Retrieved from: http://www.abc.net.au/news/2017-01-08/chineseair-pollution-crisis-caused-by-ongoing-coal-use/8168702

Chandler, D. (2008). Human Security: The Dog That Didn't Bark. Security Dialogue, 39(4), 427-438

Danso, J. \& Donkor, E. K. (2017). Caritas Ghana holds two-day dialogue on Land Grabbing. Retrieved from: http://www.ghananewsagency.org/social/caritasghana-holds-two-day-dialogue-on-land-grabbing-126608

Galtung, J. (1996). Peace By Peaceful Means - Peace and Conflict, Development and Civilization, London: Sage Publications

Gasper, D. (2013) Climate Change and the Language of Human Security. Ethics, Policy \& Environment, 16(1), 56-78

Guri Yangmaadome, B., Banuoko F., Daniel, K. Derbile, E., Hiemstra, W. and Verschuuren, B. (2012).'Sacred groves versus gold mines: biocultural community protocols in Ghana' in A. Holly, N. Kenton, and A. Milligan (eds) Biodiversity and culture: exploring community protocols, rights and consent, pp. 121-130, London: The International Institute for Environment and Development

Klein, N. (2007). October) Disaster Capitalism - The New Economy of Catastrophe. Harpers Magazine, 47-58

Krause, K. (2014). 'Critical Perspectives on Human Security' in M. Martin and T. Owen (eds) Routledge Handbook of Human Security, pp. 297-307, London: Routledge

Martin, M. and Kostovicova. D. (2014). 'From Concept To Method: The Challenge of a Human Security Methodology' in M. Martin and T. Owen (eds) Routledge Handbook of Human Security, pp. 297-307, London: Routledge

Paris, R. (2001). Human Security: Paradigm Shift or Hot Air? International Security, 26(2), 87-102

Schanz, H. (2012). Hvorfor er idéhistorie vigtig? Retrieved from: http://baggrund.com/idehistorie/

Tadjbakhsh, S. (2014). 'In Defense of The Broad View of Human Security' in M. Martin and T. Owen (eds) Routledge Handbook of Human Security, pp. 43-57, London: Routledge

UNDP (1994) Human Development Report 1994. New York: Oxford University Press. Pp. $22-40$

UNDRIP (2008). United Nations Declaration on the Rights of Indigenous. Retrieved from: http://www.un.org/esa/socdev/unpfii/documents/DRIPS_en.pdf 
UNTFHS (2009). Human Security In Theory And Practice. Retrieved from: http://www.un.org/humansecurity/sites/www.un.org.humansecurity/files/human_s ecurity_in_theory_and_practice_english.pdf

Van Schendel, W. (2005). 'Spaces of engagement: How borderlands, illicit flows, and territorial states interlock'. In W. Van Schendel and I. Abrahams (eds.) Illicit flows and criminal things: States, borders, and the other side of globalization, pp. 38-68. Bloomington and Indianapolis: Indiana University Press.

Wallace-Wells, D. (2017). The Uninhabitable Earth. Retrieved from: http://nymag.com/daily/intelligencer/2017/07/climate-change-earth-too-hot-forhumans.html 